\title{
Cooperative Learning With Undergraduate Hispanic Students: Results And Professors' Interviews
}

Bobbette M. Morgan, University of Texas at Brownsville and Texas Southmost College, USA Bret Lefler, University of Texas at Brownsville and Texas Southmost College, USA

Ruth A. Keitz, University of Texas at Brownsville and Texas Southmost College, USA

\begin{abstract}
Classes of undergraduate Hispanic students assigned to two professors were identified to determine the level of cooperative learning being implemented and to allow the professors to reflect on their experiences over a full semester. Pre-semester and post-semester surveys were completed by each of the undergraduate students. This study is based upon theories of social interdependence, cognitive development, and behavioral learning. The surveys were completed by the university students to determine their experiences in: 1) individual learning, and 2) learning with a partner(s). Interviews of the professors are included. Results of the surveys were analyzed. Results are reported. The authors also share lessons learned.
\end{abstract}

Keywords: cooperative learning, undergraduate education, minority population

\section{INTRODUCTION}

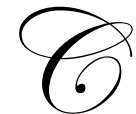

ooperative learning requires much more than simply putting students in groups as many educators believe. By giving undergraduate students the opportunity to work alone and in small groups this project increased their awareness concerning individual learning and working in small groups of two's or three's. The study also produced challenges and learning opportunities for all the researchers and professors involved.

\section{PURPOSE}

The purpose of the research is to share with educators results regarding undergraduate Hispanic students and their experiences with cooperative learning. Survey results are summarized. The convenient sample consisted of undergraduates enrolled in two different professors' Fine Arts courses. Thirty-six students completed both pre- and post-surveys providing for a paired samples test for t. Participants were primarily first and second-generation immigrants from Mexico, South America, and Cuba and often the first in their family to attend college.

\section{PERSPECTIVES}

The theoretical framework for this paper centers on cooperative learning. Cooperative learning has its roots in the theories of social interdependence, cognitive development, and behavioral learning. Some research provides exceptionally strong evidence that cooperative learning results in greater effort to achieve, more positive relationships, and greater psychological health than competitive or individualistic learning efforts (Johnson, Johnson, \& Holubec, 1994).

Social interdependence theory views cooperation as resulting from positive links of individuals to accomplish a common goal. The Gestalt psychologist Kurt Koffka proposed in the early 1900's that although groups are dynamic wholes, the interdependence among members is variable. Kurt Lewin (1948) stated that interdependence from common goals provides the essential essence of a group. This interdependence creates groups that are dynamic wholes. The power of the group is such that a change in any member or subgroup directly changes any other member or subgroup. 
Within cognitive development theory, cooperation must precede cognitive growth. Cognitive growth springs from the alignment of various perspectives as individuals work to attain common goals. Both Piaget and Vygotsky saw cooperative learning with more able peers and instructors as resulting in cognitive development and intellectual growth (Johnson, Johnson, \& Smith, 1998).

The assumption of behavioral learning theory is that students will work hard on tasks that provide a reward and that students will fail to work on tasks that provide no reward or punishment. Cooperative learning is one strategy that rewards individuals for participation in the group's effort.

The Johnson and Johnson model of Cooperative Learning includes the following five elements:

- Positive Interdependence — creating the feeling that the group "sinks or swims together."

- $\quad$ Face-to-Face Interaction - each team needs to sit in close proximity, eye-to-eye and knee-to-knee.

- $\quad$ Individual Accountability — each person must know the material.

- $\quad$ Social Skills — each student must work at implementing the selected social skill and the instructor must monitor for its use.

- $\quad$ Processing - the opportunity to reflect on how well they functioned as a team and what they can do next time to be even better.

From their review of the research on collaborative learning in higher education, Elizabeth Barkley, Patricia Cross, and Claire Major (2005) have found abundant evidence that collaborative learning is an effective and motivating format for non-traditional underrepresented racial and ethnic groups, working-adult students, commuters, and re-entry students. Collaborative learning reframes the student role by requiring students to shift from a passive, privatized, and competitive learning to active, public, and cooperative ways of working (National Learning Communities Project, 2003).

The widespread use of cooperative learning is due to multiple factors. According to Johnson and Johnson (2002) three of the most important factors are that cooperative learning is clearly based on theory, validated by research, and operationalized into clear procedures educators can use.

There are over 900 research studies validating the effectiveness of cooperative learning over competitive and individualistic efforts. This body of research has considerable generalizability: for more than 110 years the research has been conducted by a wide range of researchers with markedly different orientations working in various settings and countries. The research participants have varied widely as to cultural background, economic class, age, and gender. Further more, a wide variety of research tasks and measures of the dependent variables have been used (Johnson and Johnson, 2002).

\section{METHODS AND DATA SOURCES}

Data collection for the quantitative study occurred over one academic semester with students attending a community university. Undergraduate Hispanic students were asked to complete pre- and post-surveys. The surveys included three different types of questions and were adapted with permission from a Johnson and Johnson survey. The students were asked to rate their knowledge of cooperative learning on a scale, to describe their experiences with cooperative learning, and to define specific terms related to cooperative learning before, and after the semester's experiences. The consistency of questions and possible response options on the pre- and post-surveys allowed researchers to make comparisons about students' knowledge of cooperative learning and perceptions of expertise before and after the course (Fraenkel \& Wallen, 1996).

Pre- and post-surveys gathered data related to cooperative learning strategies students experienced and interviews of professors provide a picture of their use of cooperative learning. The paired pre- and post paired samples test for $t$ provided results for analysis.

The professors were interviewed after the semester was completed. Assumptions by the researchers were examined after reviewing the results. 


\section{RESULTS}

The pre- and post-semester paired samples test results, that included Likert-type responses on a scale of $5=$ high and $1=$ low, were summarized for all 32 questions. Using SPSS software, pre- and post-semester paired samples test for " $\mathrm{t}$ " results compared students in two professors' classrooms.

Data for the two professors' 38 students were reviewed for levels of significance using a Paired Samples Test for $\mathrm{t}$ and $p<.10$ for pre- and post-survey results. The following chart summarizes the items that were found to be significant in both classrooms using the SPSS software:

\section{Student Pre- and Post-Survey Results}

\begin{tabular}{|c|l|c|c|}
\hline Item \# & $\begin{array}{l}\text { Five point Likert scales used, 5=Highest and } 1=\text { Lowest. } \\
\text { Note: } \mathrm{t}(23)=1.320, \mathrm{p}<.10 \text { for Prof. } 1 \text { and } \mathrm{t}(13)=1.350, \mathrm{p}<.10 \text { for Prof. } 2 .\end{array}$ & Prof. 1 & Prof. 2 \\
\hline 6 & I believe that cooperative learning increases student participation in learning activities. & 1.664 & \\
\hline 10 & I believe that cooperative learning encourages and improves the performance of low ability students. & 2.192 & 1.449 \\
\hline 11 & I believe that using cooperative learning is an efficient teaching technique. & 1.723 \\
\hline 15 & How would you rate your theoretical knowledge regarding cooperative learning? & 3.092 \\
\hline 16 & $\begin{array}{l}\text { How would you rate your knowledge regarding the effective implementation of cooperative learning as a } \\
\text { model of teaching? }\end{array}$ & 2.237 & 1.897 \\
\hline 18 & $\begin{array}{l}\text { When we work together in small groups, we cannot complete an assignment unless everyone } \\
\text { contributes. }\end{array}$ & 1.596 & \\
\hline 21 & When we work together in small groups, everyone's ideas are needed if we are going to be successful. & 1.549 & \\
\hline 23 & In this class, I can learn important things from the other students. & 1.745 \\
\hline 29 & I have lots of questions I never get a chance to ask in class. & 1.577 & \\
\hline 32 & Working in a jigsaw helps me learn assigned material. & 1.924 & \\
\hline
\end{tabular}

The professors teaching the classes were interviewed. One of the professors is male and the other female. One earned a doctorate in 2006 and the other in 1972. Professor 1 had the experimental group and Professor 2 had the control group. The following chart summarizes their responses to the questions.

Interview Results: Professors

\begin{tabular}{|c|c|c|}
\hline & Professor 1 & $\begin{array}{ll}\text { Professor } 2 \\
\end{array}$ \\
\hline \multirow[t]{2}{*}{1.} & How do you define cooperative learning? & How do you define cooperative learning? \\
\hline & $\begin{array}{l}\text { Students working in small groups of } 2-3 \text {, in or out of class, } \\
\text { sharing with one another in class. In cooperative learning } \\
\text { everyone has to provide input and agree on responses. All are } \\
\text { responsible for participating actively. }\end{array}$ & $\begin{array}{l}\text { Any group activity or exercise working together for a } \\
\text { common goal. }\end{array}$ \\
\hline \multirow[t]{2}{*}{2.} & How do you define group work? & How do you define group work? \\
\hline & $\begin{array}{l}\text { In group work one person could do all the work and others not } \\
\text { have any involvement. }\end{array}$ & $\begin{array}{l}\text { Group work is pretty much the same thing as cooperative } \\
\text { learning. }\end{array}$ \\
\hline \multirow[t]{2}{*}{3.} & What size groups do you usually use? & What size groups do you usually use? \\
\hline & I like $2-3$ in a group, a maximum of 4. & I use pairs or threes. \\
\hline \multirow[t]{2}{*}{4.} & What kinds of group assignments do you give? & What kinds of group assignments do you give? \\
\hline & $\begin{array}{l}\text { When I develop my lesson plans, I build in specific questions } \\
\text { for students to turn to a partner and discuss. This way } \\
\text { everybody has an opportunity to express an opinion. I have } \\
\text { assigned cooperative research papers and have students do a } \\
\text { private evaluation of each group member. Everyone knows } \\
\text { this in advance. Joint PowerPoint presentations were also } \\
\text { effective. Everyone has an assigned responsibility-secretary, } \\
\text { reporter, timer, etc. }\end{array}$ & $\begin{array}{l}\text { I have students, working in pairs, they critique their work and } \\
\text { the work of their classmates. I have developed a critique } \\
\text { form to provide feedback from student teams to students. } \\
\text { Scenarios of classroom situations are given to pairs to discuss } \\
\text { and jointly come to consensus. Large group discussion } \\
\text { centers on input from all groups. I also have students do class } \\
\text { votes. They organize the student [art] pieces from first to last. } \\
\text { This is "real world" as art shows are juried and financial } \\
\text { rewards are involved. }\end{array}$ \\
\hline
\end{tabular}




\begin{tabular}{|c|c|c|}
\hline 5. & $\begin{array}{l}\text { What advantages do you see to using cooperative learning } \\
\text { groups? }\end{array}$ & $\begin{array}{l}\text { What advantages do you see to using cooperative learning } \\
\text { groups? }\end{array}$ \\
\hline & $\begin{array}{l}\text { This forces students to think about and reflect on the image. It } \\
\text { opens their eyes to other points of view. I learn from students, } \\
\text { too. They see things I don't see. }\end{array}$ & $\begin{array}{l}\text { Spurs discussion, gets students talking about the art, and } \\
\text { expands their ideas. It also helps them hone in on a position, } \\
\text { directs their thinking, and give focus to what they think. }\end{array}$ \\
\hline \multirow[t]{2}{*}{6.} & $\begin{array}{l}\text { What disadvantages or barriers have you experienced related to } \\
\text { cooperative learning? }\end{array}$ & $\begin{array}{l}\text { What disadvantages or barriers have you experienced related } \\
\text { to cooperative learning? }\end{array}$ \\
\hline & $\begin{array}{l}\text { It takes time to have students discuss issues, so I cover less } \\
\text { information in a class period. I like that the discussion shifts the } \\
\text { structure of the class from teacher centered to student centered. } \\
\text { Students not only learn the material, but have an in-depth } \\
\text { understanding of it. Another concern is the few students who } \\
\text { don't do their fair share. I talk to them individually about class } \\
\text { expectations. }\end{array}$ & $\begin{array}{l}\text { Someone who does not want to share the work assigned. I } \\
\text { make both parties accountable. It is a social factor. } \\
\text { Sometimes they are just visiting and not on topic. } \\
\text { Intervention is needed. }\end{array}$ \\
\hline \multirow[t]{2}{*}{7.} & Which students benefit most? & Which students benefit most? \\
\hline & $\begin{array}{l}\text { Those most likely not to participate in whole class large group } \\
\text { discussion. It helps those lacking in social or academic skills. } \\
\text { Cooperative learning benefits high achieving students, too. } \\
\text { They see they can share with other students. Responses are } \\
\text { more in-depth, beyond minimums. The more experienced } \\
\text { students bring synthesis of knowledge. It is the students that } \\
\text { demonstrate how all this "fits." }\end{array}$ & $\begin{array}{l}\text { All of them-it is a positive thing. Two heads are better than } \\
\text { one. }\end{array}$ \\
\hline
\end{tabular}

Based on experience, the researchers' expectations were for a much larger number of items to be significant. What happened? Barriers encountered included:

a. The institutional review process was slow in responding to the request for approval. Research projects had previously received timely review and approval. This resulted in an unexpected delay.

b. When the request was reviewed, two professors were not aware that they needed to complete the Collaborative Institutional Training Initiative (CITI), on-line Human Research Curriculum certification and the third person's would expire before the project would be completed. All three successfully completed their certification and proceeded with the pre- and post-survey data collection.

c. Classes of the two professors were to provide pre- and post- matched samples. One class produced 24 matched pairs and three unmatched documents and the other produced 13 matched pairs and 14 unmatched (pre- only, postonly, or unknown). Many of the 14 came from freshman in an early morning class. Efforts were made to encourage students to improve attendance and also to decrease tardiness.

d. The Paired Samples t-test was originally calculated at $\mathrm{t}(23)=1.714, \mathrm{p}<.05$ and $\mathrm{t}(13)=1.771, \mathrm{p}<.05$ was changed to $\mathrm{t}(23)=1.320, \mathrm{p}<.10$ and $\mathrm{t}(13)=1.350, \mathrm{p}<.10$. Going to $\mathrm{p}<.10$ increased the number of significant items from five to eleven.

e. Time was an issue. One professor taught four courses and worked with 150 students. This professor always includes an essay on exams, and research papers to promote student understanding and improve their writing skills. Detailed feedback is provided. The other professor taught seven classes and supervised two sections of student teachers for a total of 40 students. The professors were responsible for the development and review of a new master's program at this time also. The workload issue at a rapidly growing community university is a challenge. The community university has almost tripled enrollment since 2000 when it was at approximately 6,000 students to over 17,000 students in 2008.

f. The original study envisioned was to have one professor's undergraduate Hispanic students serve as a control group and the other be provided with additional training in cooperative learning. The assumption was made that the additional training was not needed. The pre- and post-paired results were then analyzed. An explanation for why approximately a third of the items were found to be significant is that both professors all ready incorporate some elements of cooperative learning into their classrooms. 


\section{CONCLUSIONS}

This study brings forth information about undergraduate Hispanic student experiences with cooperative learning in general through pre- and post-tests and professors' input about their classes, ideas about cooperative learning and its benefits and barriers through interviews. The undergraduate students and professors were involved in the project over the period of a sixteen week semester.

The researchers discuss challenges encountered in the project, as well as insights into conducting research. The assumption that additional training was not needed appears to be incorrect. The interviews at the end of the semester indicate that both were using cooperative learning strategies part of the time. If interviews were conducted with professors sooner, instead of at the end of the sixteen weeks, the researchers could have modified the process by providing more training and support to the experimental group. It was at the end of the semester when professors were interviewed individually. It is at this time that the researchers found that both were using some group and/or cooperative activities. A more careful selection of experimental and control groups will be used when this study is repeated. Interviews will be conducted first with faculty to better determine their levels of expertise. Discussion was not enough.

An additional result of the study is to remind us, as researchers, that thorough preparation, organization, monitoring, and follow-up are essential, and that we often learn the most from our work when situations arise that are unexpected.

\section{AUTHOR INFORMATION}

Bobbette M. Morgan, Ed. D., an Associate Professor, is a member of the School of Education in the Curriculum and Instruction Department at The University of Texas at Brownsville and Texas Southmost College. Her areas of interest include cooperative learning, adult learning strategies, brain-compatible learning and models of teaching. She currently serves as Director of the Doctoral Program.

Bret Lefler, Ph. D., Assistant Professor, is a member of the College of Liberal Arts in the Fine Arts Department at The University of Texas at Brownsville and Texas Southmost College. His areas of interest include art in middle schools and two dimensional art.

Ruth A. Keitz, Ph. D., Senior Lecturer, is a member of the College of Liberal Arts in the Fine Arts Department at The University of Texas at Brownsville and Texas Southmost College. Her areas of interest include collage and mixed media as well as promoting student success of students in art appreciation and art history.

\section{REFERENCES}

1. Barkley, E. F., Cross, K. P. \& Major, C. H. (2005). Collaborative learning techniques: A handbook for college faculty. San Francisco, CA: Jossey-Bass.

2. Carspecken, P. F. (1996). Critical ethnography in educational research: A theoretical and practical guide. New York: Routledge.

3. Fraenkel, J. R. \& Wallen, N. E. (1996). How to design and evaluate research in education ( ${ }^{r d}$ ed.). New York: McGraw-Hill.

4. Johnson, R. T. \& Johnson, D. W. (1994). An overview of cooperative learning. [on-line]. Available: http://www.co-operation.org [date accessed: 6-30-04]

5. Johnson, D., Johnson, R., \& Holubec, E. (1994). Cooperative learning in the classroom. Alexandria, VA: Association for Supervision and Curriculum Development.

6. $\quad$ Johnson, D., Johnson R., \& Smith, K. (1998). Cooperative learning returns to college. Change. 30 (4): 26-35.

7. Krathwohl, D. R. (1993). Methods of educational and social science research: An integrated approach. New York: Longman.

8. Lewin, K. (1948). Resolving social conflicts. New York: Harper.

9. National Learning Communities Project (2003). The pedagogy of possibilities: Developmental education, collegelevel studies, and learning communities. Monograph Series: The Washington Center for Improving the Quality of Undergraduate Education at Evergreen State College in Cooperation with the American Association for Higher Education. 
NOTES 